\title{
SCIENCE.-Supplement.
}

FRIDAY, DECEMBER 24, 1886.

\section{THE BASIS OF A GRADED SYSTEM OF SCHOOLS.}

HERBERT SPENCER, in his treatise on education, says, "To prepare us for complete living is the function which education has to discharge, and the only rational mode of judging of an educational course is to judge in what degree it discharges such function." Froebel's doctrine, that "education is the complete unfolding of the whole being of man," indicates how we are to be prepared for complete living, since complete living can only be realized by one perfectly developed in all his powers. The value of an educational course, then, is to be measured by the degree in which it develops all the powers of the man. And thus Joseph Payne sums up his consideration of the purpose of education by defining it as " the cultivation of all the native powers of the child by exercising them in accordance with the laws of his being, with a view to development and growth."

Since the possibility of complete living necessitates the cultivation of all the native powers of the child, it is plain that a system of schools should be so constituted that all the appliances used and all the studies prescribed shall tend towards the development of power. The unfolding of the whole being necessarily comprehends the cultivation of the bodily, mental, and moral powers. A system that does less than this fails to discharge its highest function in preparing for complete living. It is not an impertinent question to ask educators whether our present educational system comes up to the requirements stated in the opening paragraph. A system may fail to realize its highest function, not by reason of its own defects, but because of unfavorable conditions. The buildings and appliances may be inadequate or defective ; teachers may be hampered by boards whose transactions are controlled by selfish or political interests ; or public sentiment may stand very much in the way of progress. Nevertheless it remains the educator's duty to plan his system with a view to the highest attainment, and to gather all possible forces under his control.

It is my wish to indicate how the public-school system should, and to some extent does, discharge its function. The usual school course covers the period between five and eighteen years of age.
According to Currie, ${ }^{1}$ school life is divided into three periods : viz., infancy, during the first six years; childhood, the next six or seven years; and youth, from that time to the eighteenth year. These periods are suggested, he says, " by so many distinct phases in the child's physical and rational being." During the first two periods, " animal enjoyment is the chief condition of life." "The period of youth unfolds itself when the mind begins to feel interest in its own exertions and to be somewhat self-sustaining in its operations." Subsequent to this, education takes on a professional or technical character, and is beyond the domain of the public school. By our laws it is the duty of the state to take in hand the education of infants, if we adopt the classification of children as suggested above. This law has been established not only by public sentiment and for public economy, but it is most necessary and right as viewed from an educational stand-point, though denied by some authorities. Children of the first two periods, from five to thirteen or fourteen, are enrolled in our elementary schools. Our youth are to be found in the high school : subsequent to that comes the normal and technical schools. .

The function of a school system being to unfold all the powers of the child, the educator's first duty is to ascertain what are the powers of children in the various stages of their development; next, what are the means and materials appropriate to the proper exercise of those powers, and what mode or method should be used to apply those means and cause the activity of the child's powers.

The powers of children between the ages of five and thirteen, that should be operated upon by a system of education, are chiefly physical, and only the simple faculties of the mind are brought into requisition. For instance : the child's love of play and other manifestations of activity are his ruling passions, and the faculties used are those which depend mainly upon the activity of the senses. In the springtime of life the body and mind are undergoing the process of growth and formation, the body building up physical power, and the mind absorbing material for future use. The appropriate training for these years is that which stimulates natural physical growth of the body and all its parts, a wholesome use of all the senses, and a systematic exercise of the faculties

1 Early and infant school education, p. 1, by James Currie. 
of observation, imagination, and memory. By such a course the skilful teacher directs the will of the child, and cultivates all his moral characteristics.

The kindergarten is the only system which furnishes the means and the methods, and is systematically arranged to provide such atraining as is suitable to children when they first enter the public schools; and the public-school system can never be complete until the kindergarten, the genuine Froebel system, is made the first step in the course. The natural exercise of the body is provided for in the games, the little hands and fingers are made skilful by the occupations, the senses are made acute by gifts, and all the faculties of the childish mind are set into activity; while at the same time a knowledge of number, form, color, symmetry, and language, is being naturally acquired.

During the later years of the elementary school, a similar course should be maintained, that would furnish all the facilities for the proper development of the physical, mental, and moral powers in their due proportion. The kindergarten work, and especially the true kindergarten spirit, should be made a part of the primary-school course. Drawing, paper-cutting, modelling, carving, sewing, etc., should occupy a fair portion of the time. It has been found that five hours of a day are too much for the intellectual labor of a child : the afternoon of school-work is of very small importance in the primary school, unless devoted to light occupations. The ordinary studies of the elementary school may be used to develop power, provided they are used according to the true principles of education. Reading, spelling, penmanship, and language are taught as one, by methods that cultivate the observation, the conceptive faculty, and the imagination. The early lessons in number, form, and drawing, tend towards the same end. Following these subjects comes geography, not to train the memory, but to further cultivate the observation and the imagination primarily. The outgrowth of this boundless study brings the child to a knowledge of other elementary sciences and of history, by all of which the faculties of the mind become exercised in the " complete unfolding of all the powers of the man."

The mistake made by the majority of teachers is in the method of presenting the subjects for study, and the methods are at fault because the purpose of study is lost sight of. The school curriculum is taught for the knowledge to be imparted instead of the power to be developed. The teacher is not alone to blame for this state of things: the examiner deserves the greater blame.
He asks how much the child knows : consequently the teacher devotes her time to imparting knowledge, by oral teaching, by explaining all difficult examples, and, in short, by doing most of the pupil's work. Why? "Because it takes too much time to wait for the children to do for themselve6," and because the pupils are not able to do for themselves, and need the teacher's help, and thus, as Spencer says, "Having by our methods induced helplessness, we make helplessness the reason for our methods." On the other hand, the teacher who teaches for the sake of the pupil and not for the sake of the subject, who employs methods that tend to develop mental power, creates self-activity, and furnishes her pupil with the means by which he can make himself his own teacher.

The elementary schools having served the purpose for which they were established, it becomes the province of the high school to make use of those powers of the mind, and acquirements in the further training of the intellectual faculties, in which, as Currie says, the mind 'begins to feel interest.' The work of the high school is designed for the cultivation of the higher faculties of the mind. The ideas already acquired are to be elaborated by generalization, judgment, and reasoning.

The unity of such a system lies in its purpose ; namely, the derelopment of power at each stage of the child's growth. Each grade or step furnishes the proper material and the proper studies for the exercise of his powers. There is an order of studies; but the order does not depend merely upon the relations of the subjects to each other, but upon their fitness for the work of development. The arrangement of studies from this standpoint differs much from old courses of study. For instance : penmanship is now taught from the beginning because it belongs with reading; lessons on hygiene and physiology begin as soon as the child is able to observe the parts of his body, and to understand their uses and need of care ; and so other elementary sciences are used to cultivate the observation of our little children. History is also taught in the primary schools to cultivate the imagination, and to awaken a love for our country and its heroes. At the same time the primary arithmetics have been purged of much of the oldtime puzzles and conundrums, while the rules of technical grammar have been deferred till a later day.

The normal school educates those who have an aptitude for teaching, a love for children, and a desire to learn to train young minds. Its methods tend to strengthen the judgment and administrative powers, and the ability to put to 
practical use the knowledge acquired, and are - based upon the same principles of education that govern the methods of the earlier schools.

Such a system is consistent in all its methods and aims ; it maintains a constant unity of purpose ; while each department is distinct in its own individuality, and bears a proper relation to the whole.

C. E. MELENEY.

\section{MR. MATTHEW ARNOLD'S REPORT ON ELEMENTARY EDUCATION ON THE CON- TINENT.}

Mr. MATTHEW ARNOLD has but lately resigned the office of her majesty's inspector of schools, a position which he has filled for many years with credit to himself, and with great benefit, we are sure, not only to such schools as have come under his immediate supervision, but also to English educational interests in general. One of his last official duties of any importance was to visit Germany, Switzerland, and France, and to write an official report on certain specified points connected with elementary education in those countries. Some portions of that report were used by Mr. Arnold in his address before the University of Pennsylvania, which was printed afterwards in the Century magazine. But the entire report is of the liveliest interest to American educators; for several of the points investigated by Mr. Arnold are those to which no little attention is being paid in this country, and all the information gathered by him is part of the material to be used by the comparative method in studying educational institutions and methods.

By the terms of Mr. Arnold's instructions, his attention was to be more particularly directed to Germany and Switzerland, and the points he was to study were four in number: $1^{\circ}$. Free education; $2^{\circ}$. Quality of education; $3^{\circ}$. Status, training, and pensioning of teachers; $4^{\circ}$. Compulsory attendance, and release from school. Only fourteen weeks were given to the inquiry; and of these, five were spent in Prussia, two in Saxony, two in Bavaria, two in Switzerland, and three in France. Mr. Arnold's latest mission, as he expressly states, differed from those of 1859 and 1865 in that he did not go now to study systems of education, but only to report on the four above-mentioned points. These points $\mathrm{Mr}$. Arnold takes up in order.

Under the head of free education, he was instructed to ascertain whether gratuitous education is confined to elementary schools, or extends to other schools or colleges; what reasons induced the state to establish the gratuitous system ; in what way (directly or indirectly) the lower classes of society are made to feel the weight of the expenditure on education; in what way the dirty and neglected children in large towns are dealt with, and especially whether all descriptions of children are mixed in the same schoolroom; whether there is a legal prohibition against charging fees in public schools, even if parents and children are willing to pay; whether the attendance of children has increased or diminished since the establishment of free schools, Mr. Arnold answers these questions first with the information gained by him in Prussia. In the Prussian constitution of 1850 is this provision : In der offentlichen volksschule wird der unterricht unentgeltlich ertheilt. But this provision has generally remained inoperative, because the popular school is to be maintained by the Gemeinde, or commune, and the communers have not in general found themselves able to forego the income from school fees. And, on the other hand, the state has not been able or willing to provide gratuitous instruction in the communes. Some few communes, however, have been able to throw their popular schools open to all classes of the population, free of all charge. Düsseldorf has done so: so has Berlin. The Berlin schools have been free since 1870 , and last year it cost more than $6,000,000$ marks to support them. At the time of the introduction of free schooling, the municipality had 49 communal schools, with 31,752 scholars; in 1885 it had 146 such schools, with 132,889 scholars. These communal schools are the only body of schools in Berlin or throughout Prussia in which school fees are not paid. Herr von Gossler, minister of education, was found by Mr. Arnold to favor making the communal schools free everywhere, and Prince Bismarck is said to agree with him. But among the public generally, including the teachers themselves and the government officials, the weight of opinion is against such a course. Even where school fees are charged, they meet but a small portion of the total expense. On an average for the whole of Prussia, school fees furnish 20.58 per cent of the cost of teaching in the popular schools; endowments, 12.02 per cent ; the communes, 55.26 per cent; and the state, 12.14 per cent. In some towns, Cologne for example, where the popular schools are not free, provision has been made for giving free instruction to poor children in schools by themselves. But in Berlin the children of the working and middle classes all attend school together. The only distinction made on the ground of poverty at Berlin is that school-books and school-material are supplied gratuitously whenever the teacher finds that the child cannot afford to buy them. 